\title{
PROTO, EARLY DYNASTIC EGYPT, AND EARLY BRONZE I-II OF THE SOUTHERN LEVANT: SOME UNEASY ${ }^{14} \mathrm{C}$ CORRELATIONS
}

\author{
Eliot Braun \\ Israel Antiquities Authority, P.O. Box 21, Jerusalem 91004. Email: eliot@ israntique.org.il.
}

\begin{abstract}
A number of recent radiocarbon determinations from several sites in Israel suggest advancing, by some considerable period of time, both the onset of the cultural horizon known as Early Bronze I and the appearance of its latest phases. The logical outcome of the acceptance of these new dates puts such a strain on chronological correlations between the ${ }^{14} \mathrm{C}$ data and the archaeological record that the entire system would no longer be tenable if they were accepted. This paper examines in detail the problematic nature of these "uneasy correlations."
\end{abstract}

\section{INTRODUCTION}

The later prehistory (from Upper Paleolithic through Early Bronze) of the southern Levant (the land mass covered by the modern polities of Israel, Jordan, the Palestinian Autonomous Authority, and Egyptian Sinai) is represented by a well known sequence of cultural facies, for which archaeologists have determined a basic relative chronology (Mazar 1990:30). For most of these periods radiocarbon determinations are the backbone of an absolute chronology that has become more and more precise with the honing of scientific methodology that allows for calibration of raw data expressed as calendric dates. They are, indeed, our only source of absolute chronology for all these millennia until the end of a cultural horizon known as EB $I,{ }^{1}$ and the beginning of the succeeding cultural phase EB II.

Initial phases of EB I are conventionally believed to follow the collapse of the Late Chalcolithic culture (Braun 1989; Joffe and Dessel 1995:512; Gilead 1994:10), though just when this event took place has been subject to debate (cf. Gilead 1994; Joffee and Dessel 1995). The other end of EB I and the beginning of the succeeding EB II period are intertwined with historical events in Egypt (Table 1) that firmly anchor the transition between them to sometime within the reign of the first king of Dynasty I and the end of the reign of its third king. ${ }^{2}$

This correlation is confirmed by the list of kings and spatially organized cemetery at Abydos in Upper Egypt (Kaiser 1957) that both mirror the chronological progression of this dynasty. Chance finds of Egyptian materials in the southern Levant have also yielded relevant archaeological data. Very briefly, the evidence for this correlation may be summarized as follows:

1. Royal symbols known as serekhs (ancient Egyptian word for "banner") that often contain the Horus $\prod_{\theta}^{\ominus} \overline{\overline{1}}$ name of a king: (Gardiner 1973:591; Wilkinson 1985; O’Brien 1996; Wignall 1998), bearing the name of (Horus) $\operatorname{Nar}(\mathrm{mer})^{3}$ — the first King of Dynasty 1 (or the last king

\footnotetext{
${ }^{1}$ Early Bronze is the term I prefer. Other scholars use alternate nomenclatures to indicate virtually the same chrono-cultural entities in the archaeological record, Proto-Urban, Late Chalcolithic and sometimes Early Canaanite.

${ }^{2}$ There is a general agreement among scholars that the onset of EB II more or less correlates with the beginning of the first Egyptian Dynasty (Hennessy 1967: 86; de Miroschedji 1976: Table 31; Callaway and Weinstein 1977:1; Tutundzic 1989; Kantor 1992 and Stager 1992: Figure 16; Amiran and Gophna 1992; Oren and Yekutieli 1992:381), although there is some dispute concerning the actual date of its occurrence. As noted by Braun (1996:135), one group places it between 3100-3050 BCE (e.g. Amiran 1978; Hassan and Robinson 1987:125; Stager 1992:40; Mazar and de Miroschedji 1996: Table 2; Hendrickx 1996:64), while a second supports the possibility of dating it as late as 2950 BCE (Ward 1991; Ben-Tor 1992; Brandl 1992:note 1).
}

(C) 2001 by the Arizona Board of Regents on behalf of the University of Arizona Near East Chronology: Archaeology and Environment. RADIOCARBON, Vol 43, Nr 3, 2001, p 1279-1295 Proceedings of the 17 th International ${ }^{14} \mathrm{C}$ Conference, edited by $\mathrm{H} J$ Bruins, I Carmi, and E Boaretto 
of Dynasty 0) — have been found at a number of sites in the southern Levant that can be dated to very late in EB I on the basis of the local material culture.

2. One serekh from the south Levantine site of Palmahim Quarry is attributable to an unnamed Egyptian king (possibly "Double Falcon"4) of Dynasty $0^{5}$. It is likely to be analogous to another fragment of a serekh from nearby Horvat 'Illin Tahtit (henceforth HIT). Notably, both these royal symbols were incised into the fabrics of locally made storage jars of a particularly rare type, associated with late (but not the latest) phases of EB I occupations at each site ${ }^{6}$. A date in Dynasty 0, before the reign of Horus Narmer, fits well with their relative local sequences. At each of these sites there is an additional Late EB I occupation that would be closely or perhaps absolutely contemporary with the reign of Horus Narmer and possibly his successor, Horus Aha (see below: Braun and van den Brink 1998).

3. Definitively EB II types of pottery ${ }^{7}$ are found in a number of royal tombs of Dynasty 1 at Abydos, beginning with that of Horus Djer (Zer), the third King following the reigns of Horus Narmer and his successor Horus Aha.

Thus, the latest phases of EB I may be definitively correlated with the end of Dynasty 0 and the beginning of Dynasty I, with the possibility of EB I ending no later than sometime early in the reign of its third king Horus Djer. The end of EB I is then firmly anchored into the historical Egyptian sequence. Accordingly, the length of the period is dependent upon the time span between the onset of EB I and the beginning of Dynasty I. On one hand, dates for the end of the Chalcolithic period and initial EB I are obscured by conflicting determinations further complicated by the lack of data, while on the other hand there are obvious difficulties with a number of suggested dates for later EB I and contemporary Egyptian events.

When did EB I begin? Traditional chronologies (e.g. Stager 1992:40; Joffe and Dessel 1995:514) suggest a date about 3500 for the onset of EB I. Recently, A Golani (1997a; Golani and Segal, forthcoming ${ }^{8}$ ) suggested (on the basis of a series of ${ }^{14} \mathrm{C}$ determinations purported to derive from EB I contexts at the site of Afridar, Area E) a date considerably earlier for the initial phase of EB I (Table 1). A second series of dates from what may be a nearby contemporary Initial EB I site (Braun 2000),

\footnotetext{
${ }^{3}$ The Horus name of this king, Narmer, is written with the hieroglyphic sign of a catfish (and a chisel). To him is attributed the unification of Upper and Lower Egypt (although we know now that this process concerns a protracted period of time) and the distinction of being the first ruler of Dynasty 1. Serekhs (incised into Egyptian pottery vessels prior to firing) of this king found in the southern Levant to date are all on fragments of vessels (e.g. Yeivin 1960; Amiran 1974; Levy et al. 1995).

${ }^{4}$ This king is identified by a hieroglyph, or perhaps more accurately, a sign representing two opposing falcons surmounting a serekh (cf. Clédat 1913).

${ }^{5}$ These rulers or elites (identified from either their monumental tombs in special portions of the royal cemetery at Abydos or from objects bearing their names within serekhs), known to have lived and died in the period preceding the unification of Upper and Lower Egypt, are assigned to "Dynasty 0".

${ }^{6}$ This king is identified by a hieroglyph or perhaps more accurately, a sign or representation of two opposing falcons surmounting a serekh (cf. Clédat 1913).

${ }^{7}$ This so-called "Abydos Ware" (Amiran 1969:59-66) is an unfortunate misnomer. It is neither a single "ware" in the sense that such a term is most frequently used in ceramic studies, nor is it definitively associated with Abydos, although examples of it have been found in quantity in the royal tombs at the site. In reality, "Abydos Ware" is an eclectic collection of Levantine pottery types of distinctive morphologies (jugs and storage jars), decorations (red burnished or painted with triangular patterns often filled with dots) and wares (i.e. fabric types; e.g. "light faced" and "metallic") imported into Egypt from the Levant (Kantor 1992:19; Porat 1987; Greenberg and Porat 1996). Examples of these Levantine imports are also found at other sites in contemporary contexts in Egypt. Their chronological significance lies in their definitive appearance after EB I, making them hallmarks of EB II.

${ }^{8} \mathrm{~A}$ summary of this paper was presented by the authors at the $3 \mathrm{rd}$ International Symposium on ${ }^{14} \mathrm{C}$ and Archaeology held in 1998 in Lyon, France.
} 


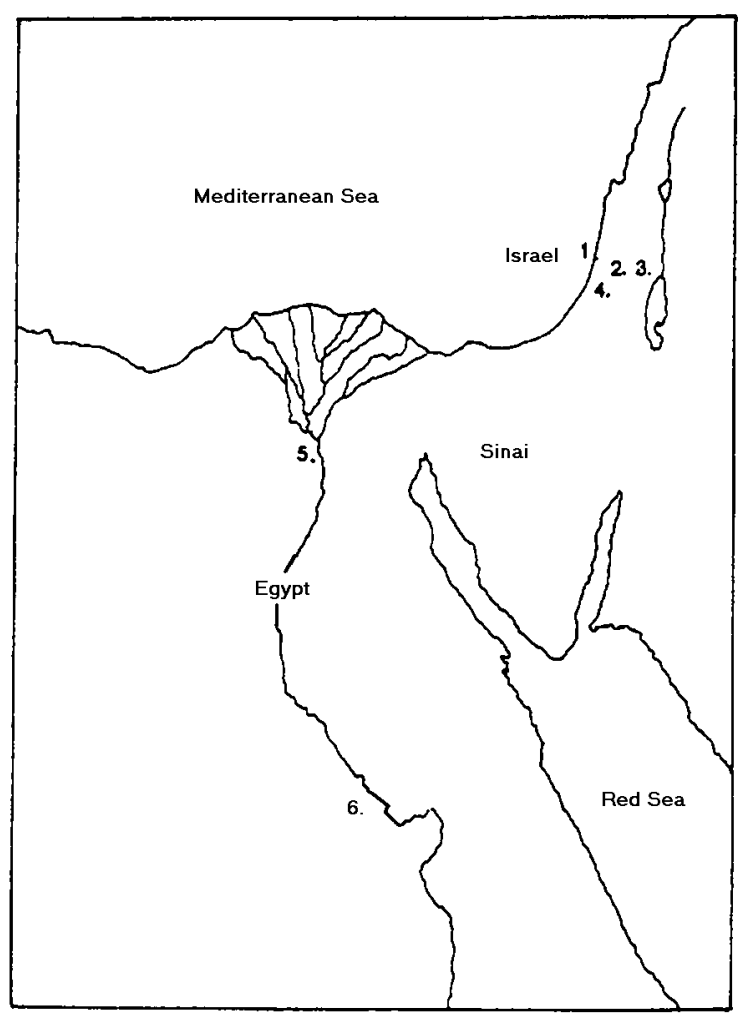

Figure 1 Sites in Egypt and the southern Levant: 1) Palmahim Quarry, 2) HIT and Hartuv, 3) Sataf, 4) Tel Erani, 5) Saqqara, 6) Abydos.

Afridar, Area G (Braun and Gophna forthcoming; Table 2) appears to corroborate a date for the beginning of this period early in the 4 th millennium BCE.

Despite these new determinations, R Gophna and myself, the excavators of Afridar, Area G, are convinced that such an early date for the beginning of EB I is highly improbable and we offer the following explanation for the data. The artifact assemblages of Areas E and G both contain fossiles directeurs (e.g. cornets and fenestrated, pedestalled basalt vessels with incised cross-hatching) of the Chalcolithic period together with EB I diagnostic material. In the case of Area G, we believe that the site was occupied earlier than Stratum 2 (first phase of EB I), from which the ${ }^{14} \mathrm{C}$ samples come. Despite the Stratum 2 find spot of the charcoal samples, they are thought to be residual, recovered in fill ultimately derived from an unexcavated occupation probably associated with the Chalcolithic period (e.g. Stratum -2 or elsewhere on the site).

An analogous scenario may explain the dates from the Afridar, Area E series, claimed as prima facie evidence for dating the EB I at the site so early. The samples from Area E derive from a site that has virtually no architecture, is replete with pits (more than 140 have been definitively identified), was cut by two later tombs, and was bulldozed prior to excavation. As in Area G, the possibility of a Chalcolithic occupation at Area E cannot be definitively ruled out for the origin of these samples.

Additional points suggesting the unlikelihood of EB I beginning so early in the 4th millennium BCE are listed below: 
1. Stratum 2 at Afridar, Area $\mathrm{G}$ is understood to represent a continuous sequential occupation within the same cultural horizon that is proximally close to Chalcolithic but is definitively EB I, termed "Initial Southern EB I" (Braun 2000).

2. This Initial EB I horizon is shown on the basis of architectural, ceramic, chipped stone, and ground stone traditions (see above and below) to be correlated with "Early Northern EB I" (Braun 1997:102-107; 2000).

3. More or less contemporary ${ }^{14} \mathrm{C}$ determinations from other Early EB I occupations at Kabri 11 in the north (Table 3) and Taur Ikhbeineh-Gaza Strip (Phase) IV ${ }^{9}$ (Table 4) in the south, have yielded significant series of ${ }^{14} \mathrm{C}$ determinations from occupational sequences that exhibit internal logic (i.e. the dating sequences reflect the stratigraphic sequence) suggesting the date for Early EB I around the middle of the 4 th millennium BCE.

4. Two ${ }^{14} \mathrm{C}$ determinations from Stratum I, Afridar, Area F (Table 5), an occupation that appears to share some of the major characteristics of the material culture of Area G (Khalaily forthcoming), date to the middle of the 4th millennium BCE or later (Table 4). A possibility that there is a gap of hundreds of years between these occupations is not tenable.

5. Several ${ }^{14} \mathrm{C}$ determinations from Chalcolithic occupations of the southern and central regions (Table 5) appear to date to the latter part of the first half of the 4th millennium BCE and seem to indicate at least some Chalcolithic occupation in the earlier centuries of the 4th millennium BCE. Our present understanding of the archaeological record precludes any overlapping of these two cultural horizons; there is just no clear-cut evidence for it.

More serious problems arise when this new dating is correlated with the archaeological record. According to a possible scenario, EB I could be lengthened by up to 450 years that-if added to the 500 or so previously ascribed to it-makes for an exceedingly long period. So far, to the best of my knowledge, there is no known sequence in EB I in the archaeological record that could possibly fill such a time span (Braun 1996:236-239). Neither is it possible to postulate a gap in occupation of the region within EB I. An overlap with Late Chalcolithic (cf. Tables 5 and 6), as indicated by ${ }^{14} \mathrm{C}$ determinations also seems wholly unrealistic, given our present understanding of the archaeological record.

If the same relative time span of about 500 years is allowed for EB I as in more traditional chronologies, then such an interpretation would necessarily entail redating the reign of Horus Narmer of Dynasty I in Egypt to hundreds of years earlier than is allowed for by even the highest Egyptian chronologies - a virtually impossible scenario (see below). Dating the EB I settlements of Afridar to early 4th millennium BCE would also considerably distance them chronologically from other related Early EB I sites (see above)—an option that does not seem feasible. Finally, if the specimens are all considered to derive from old wood and residual olive stones-a possibility that does not seem likely but cannot be totally discounted — that would speak for a later date of the EB I occupations at Afridar.

Arguments for accepting proposed changes for the date of an initial phase of EB I seem rather less cogent than those against their acceptance cited above. The direct association between the samples

\footnotetext{
${ }^{9}$ Admittedly, Phase IV is not the earliest evidence of EB I from the site, but information available (Oren and Yekutieli 1992) suggests there are no major differences (i.e. time span) between the material assigned to the pits (Phase IV) from which the ${ }^{14} \mathrm{C}$ determinations derive and the matrix (Phase 5) into which they were cut (Oren and Yekutieli 1992: Fig. 11). Much of that material is paralleled in the Area $\mathrm{G}$ assemblage.
} 
and the EB I period remains tenuous and in need of a considerably higher standard of proof than has been offered. The new dates would, however, fit in particularly well with Gilead's (1994:296) hypothesis that suggests a major gap in settlement between the end of the Chalcolithic and the beginning of EB I-however problematic it may be to explain such a hiatus. It appears that dating the Late Chalcolithic of the Beersheva region to the end of the 5th millennium BCE would likely entail a landscape rather barren of people if one does not accept the dates for the Chalcolithic occupations presented in Table 6. Gilead's suggestion that the only Late Chalcolithic in southern Israel is found in the Nahal Mishmar Cave seems much less possible with Aardsma's $(2000: 9 ; 2001)$ new determinations for the mats, in which the hoard of Chalcolithic objects was wrapped. These early dates are corroborated by two additional determinations from remains of straw mats in nearby deposits (Table 3). They indicate the Chalcolithic deposit (i.e. the treasure) should actually be dated to the second half of the 5th millennium BCE, thus leaving Gilead with no evidence for any early 4th millennium BCE occupations. Golani's and Segal's (forthcoming) suggestion for redating the beginning of EB I has the merit of filling this gap or providing evidence of an overlap between these cultural horizons. However, it lacks substance to make it credible.

\section{${ }^{14}$ C DETERMINATIONS AND LATE EB I}

As noted in the introduction, the end of EB I is closely correlated with the beginning of Dynasty I in Egypt (Table 7). Unfortunately, this correlation offers little help for determining absolute chronology, because there are no good absolute dates for the reigns of this dynasty based on non-radiometric data. Conventional scholarship holds the reign of Narmer to be between 3150 BCE and 2950 BCE (e.g. Kantor 1992:13-14; Stager 1992:40; DHKPRP 1999:29). The extreme dates in this range reflect respectively what is sometimes referred to as "high" and "low" Egyptian chronologies (Redford 1992) ${ }^{10}$ that were arrived at by extrapolating from later chronological markers (i.e. Egyptian recording of the rise of Sirius [the morning star]; DHKPRP 1999:28-29). The dependence on king lists representing reigns of non-quantifiable length and counting backward by choosing from several fixed points explain this significant 200-year difference between chronological schemes.

Such imprecision in chronology has encouraged scholars to turn to ${ }^{14} \mathrm{C}$ determinations for succor in establishing the absolute chronology of the end of EB I and its contemporary period in Egypt. Rather unfortunately, data available so far present some formidable problems in interpretation. In some instances, traditional chronologies based on the abovementioned historical considerations actually conflict with calibrated ${ }^{14} \mathrm{C}$ dates.

Some ${ }^{14} \mathrm{C}$ dates from Egypt (Table 8), such as several ones from the Abydos cemetery, seem to confirm a conventional (i.e. high) dating. Tomb U-j of King Scorpion ${ }^{11}$ (probably the earliest of several kings who reigned before Narmer, and who is appropriately buried in a precinct used in Protodynastic times) offers some interesting ${ }^{14} \mathrm{C}$ determinations. If we exclude $\mathrm{Hd}$ 13058-1295 (3362 BCE, calibrated) as being likely to have been a sample of somewhat aged material, and we take 2 dates with the greatest probability within the 1-sigma range from the remaining two samples, we get a date between 3327 and 3223 BCE for Hd 13057-1295 and 3376-3335 BCE for Bin 4673. These latter

\footnotetext{
${ }^{10}$ These chronologies essentially deal with events of the second millennium, especially connected with Hyksos and Middle Bronze Age activities. In addition to high and low chronology, there is also "middle chronology" (Redford 1992:104, note 23).

${ }^{11}$ This king is identified by his representation associated with objects in his Tomb (designated " $\mathrm{j}$ ” in Cemetery U) at Umm elQaab (Dreyer 1998) and is not to be confused with King Scorpion associated with a ceremonial macehead of a later period (Emery 1961:42).
} 
dates are in essential agreement for a conventional, "high" chronology, although they offer no great precision.

It should be noted that the time span possible according to historical information on these kings is somewhat dependent upon the number of kings and the lengths of reigns between Horus Scorpion I (of Dynasty 0) and Horus Narmer (Wilkinson 1999:52-58). For the present, given our knowledge of the archaeological record, these data remain, respectively, conjectural and non-quantifiable. Thus, in this instance there is no conflict between the ${ }^{14} \mathrm{C}$ determinations and conventional chronological schemes.

Radiometric determinations from the tomb of Aha, Narmer's successor, place the end of his reign almost within the conventional chronological framework. Accordingly, if for Hd 13054-1292 a probability of 0.396 within the $1 \sigma$ range is chosen, then the calibrated date for the tomb indicated is between $3231 \mathrm{BCE}$ and $3172 \mathrm{BC}$. From the conventional view, a more acceptable dating, albeit with a slightly lesser probability of 0.303 , is represented by a range between $3160 \mathrm{BCE}$ and 3117 BC. It is interesting to note that Hd 13055-1294, from the same tomb at Saqqara, gives us rather earlier dates with the highest probability. This determination should probably be attributed to a specimen somewhat more aged than the others, a phenomenon noted often in Egypt (e.g. DHKPRP 1999: $29,33)$.

Within this traditional chronological scheme there is some difficulty explaining the cluster of 4 dates out of 9 determinations of ${ }^{14} \mathrm{C}$ (Table 9) from a site in the modern town of Beth Shemesh, Israel, HIT. It is a Late EB I site with two destruction levels (Stratum IV succeeded by Stratum III) representing virtual continuity of occupation. All the ${ }^{14} \mathrm{C}$ samples come from these two strata dated later than Tomb U-j at Abydos and prior to the onset of EB II (Table 7).

The relative dates of the EB I occupational strata at HIT are fixed by conventional chronological markers, local ceramics, and by two Egyptianized objects. Pottery types from these levels are well attested to at the Late EB I occupations of Arad IV and another site, Palmahim Quarry, that has an especially close association with HIT. Two locally made storage jars of a rare type found until now only at HIT and Palmahim Quarry were incised before firing with royal symbols, serekhs of an unknown king of Dynasty 0 (Braun and van den Brink 1998). ${ }^{12}$

The HIT serekh is only a tiny fragment, but the serekh from Palmahim Quarry is complete. E C M van den Brink (Braun and van den Brink 1998) considers them to be coeval and dates them on the basis of stylistic considerations of the complete serekh to sometime early within Dynasty 0 in Egypt. He believes the Palmahim Quarry serekh may be associated with the ruler known as "Double Falcon", one of the successors of King Scorpion (I; see below). The upper limits of the dates of these vessels somewhere within Late EB I and prior to EB II are confirmed by the absence of the so called "Abydos Ware". Both HIT and Palmahim Quarry seem to have been abandoned before this pottery made its appearance.

A lower limit for their dates is indicated by the complete absence at HIT of another collection of EB I pottery types related to an earlier phase of the period ${ }^{13}$ known as Erani $\mathrm{C}$ after the stratum and tell where it was dominant (Kempinski and Gilead 1991). Notably, this same type of pottery also domi-

\footnotetext{
${ }^{12}$ These two serekhs are the only ones known from the southern Levant to be incised on local pottery. In addition, the Palmahim Quarry specimen is the earliest so far attested to in the southern Levant (The HIT specimen is too non-diagnostic to say anything specific about the ruler or its date).

${ }^{13}$ Study of the large and well preserved assemblage of pottery from HIT has failed to turn up even one sherd of this earlier type.
} 
nates an EB I assemblage at the site of Hartuv. Hartuv is a mere kilometer from HIT and the possibility that these two EB I settlements could have existed coevally and not shared pottery traditions is unthinkable. Clearly, Hartuv must have ceased to exist before HIT was resettled ${ }^{14}$ in Late EB I.

Affirmation of this sequence is actually obtained from Abydos/Umm el-Qaab. Erani C type pottery is found in Tomb (U-j) of King Scorpion (Braun and van den Brink 1998), who precedes Double Falcon in Dynasty 0. The Late EB I Stratum (2) in which the serekh of Double Falcon was found at Palmahim Quarry must, therefore, be dated later than Tomb U-j. On typological grounds (based on the serekh bearing jars and a large selection of additional local pottery types) the Stratum IV occupation at HIT can be shown to be closely contemporary, if not absolutely with Palmahim Quarry 2 and also Stratum IV at Arad (Amiran 1978). Thus, based on local ceramic sequences and historical considerations of the sequence of rulers in Dynasty $0,{ }^{15}$ Strata IV and III at HIT must post-date Hartuv and belong to the latest phases of EB I.

One date from the EB I site at Hartuv (RT-924B ${ }^{16} 6$; Table 9) suggests, according to this cluster of early dates from HIT, that settlement to be contemporaneous to that at HIT (Stratum IV). However, as noted above, it belongs to an earlier cultural horizon. Thus, the dates from these sites are problematic and need to be explained. Interestingly, a calibrated date from Sataf (Gibson et al. 1991; Table 3), a site in the Judaean Hills with a pottery assemblage reminiscent of that of Hartuv ${ }^{17}$ that cannot be much removed in time from it, seems to corroborate the earlier Hartuv radiometric determination. Although the entire choice of possible dates for the Sataf grape seeds is almost four centuries, the time spans of 3502-3430 BCE and 3380-3326 BCE (within the 1- $\sigma$ range) have substantial probability factors $(0.308$ and 0.275 , respectively) that argue for their validity.

Given our understanding of relative chronology it would seem that ${ }^{14} \mathrm{C}$ determinations RT 1573, RT 1602, RT 1603, and RT 1660 from HIT (Table 9) are all too early for this occupation. These dates can, however, be explained by the "old wood effect" and we need not trouble too much about them. More disturbing is the date derived from Emmer wheat (RT 1604) from this site-the single shortlived sample. Notably, it was recovered from the later EB I level (Stratum III) and may date from within Dynasty 0 (later than "Double Falcon") to as late as some time during the reign of Aha, second king of Dynasty I.

The multiple (6) intercepts for this determination leave us with some uncomfortable choices. The range with the highest probability $(0.420)$ is between $3334 \mathrm{BCE}$ and $3255 \mathrm{BC}$, dates that suggest close chronological proximity with Hartuv and, therefore, are highly unlikely (see above). According to our best understanding of the dating of these reigns, the only reasonable calibrated choices for this determination must fall into the latest dates within the $1-\sigma$ range. However, the probability of

\footnotetext{
${ }^{14}$ There is evidence of a sedentary occupation in the Neolithic period at the site.

${ }^{15}$ The internal sequence of rulers or elites of Dynasty 0 is based on traditional scholarship that especially considers ceramic typologies. ECM van den Brink brought the following information to my attention in personal communication saying: "Traditional scholarship considers Scorpion I to be earlier than "Double Falcon" by a recognition that the few complete preserved storage jars incised with the serekh signs attributed to "Double Falcon" (from el-Beda, N. Sinai, and Turah in Lower Egypt) belong morphologically to van den Brink's (1966) Type IIa jars that are found in association with Petrie's (1953) cylindrical jar types W 71-85. Therefore, they are securely dated to the Naqada IIIb1 period (van den Brink 1996:153 and Table 5). On the other hand, Scorpion I is identified by an earlier group of ink-inscribed cylindrical jars bearing his name. These jars are of Petrie's types W 50/51 (e.g. Dreyer 1992:297, pl.4) and are dated to the preceding Naqada IIIa2 period (e.g. Dreyer 1992: 296; 1998)."

${ }^{16}$ Two determinations were made from the same piece of "charred wood". RT 924A seems to have produced an impossible date late in the 3rd millennium BCE (Table 3).

${ }^{17}$ This includes a few examples of Erani $\mathrm{C}$ type pottery (see above).
} 
these determinations (0.185), between 3190-3154 BCE and 3135-3098 BC, seems almost absurdly low. A choice of dates within the 2- $\sigma$ range either lacks precision or similarly suffers from an extremely low probability factor.

Another ${ }^{14} \mathrm{C}$ determination (Table 9) is from seeds in a Stratum 1 context at Palmahim Quarry ${ }^{18}$ (Braun and van den Brink 1998) that is very close in time to or perhaps even absolutely contemporary with HIT, Stratum III (see above). This determination offers what appears to be a more acceptable date for a very Late EB I cultural horizon 3104 BCE to 2910 BC. It, too, is based on a shortlived sample and comes from a secure archaeological context (Braun and van den Brink 1998). Significantly, Stratum III at HIT, after a violent conflagration completely destroyed it, was immediately resettled, while Stratum 1 at Palmahim Quarry represents continuous development from the preceding occupation. This continuity is evident in each instance in ceramic and architectural traditions that not incidentally are common to both sites.

Although noteworthy, the inconsistency between the ${ }^{14} \mathrm{C}$ determinations from Palmahim Quarry and HIT is, after all, based on only two determinations. Despite the short-lived nature of the material used, the sample is far too small to be in any way definitive. It is lamentable that additional determinations that might ameliorate some of the problems of chronological discrepancies between these sites could not be obtained. ${ }^{19}$

A recently published series of high-precision dates tends to corroborate the framework of traditional chronologies that place the end of EB I around the end of the 4th millennium BCE. A Late EB I phase (1) at Tel Abu al-Kharaz is correlated with Naqada IIIB (mid to late Dynasty 0) and Dynasty 1 (Fischer 2000:Table 12.3) and is cited as likely to fall between 3200 and 3100 BCE. The end of EB I and the beginning of EB II are, accordingly, dated to about 3100-2900 BCE. Notably, these dates are almost all based on samples derived from clear stratigraphic contexts; many are also short-lived. Of interest in this connection are two dates from charred seeds from Tel Bet She'an (Segal and Carmi 1996:88) that suggest a similar range for what is understood as a late phase of EB I (Amihai Mazar, personal communication 2001).

\section{SUMMARY}

This paper argues for a broad approach to the chronology of the EB Age in the southern Levant that applies ${ }^{14} \mathrm{C}$ determinations to a holistic study of the archaeological record. For example, typological ceramic studies have been painstakingly developed through decades of cumulative field experience and research (e.g. Amiran 1969) and to disregard them is impossible. To ignore such obvious connections in material culture as those between the Afridar Early EB I sites, Kabri 11 and Taur Ikhbeineh Phase IV, and to postulate a very lengthy to extraordinary long span of time between these occupations, contra other evidence in favor of ${ }^{14} \mathrm{C}$ determinations would be permissible if their EB I association were beyond question. Even then, and especially in such a scenario, one would need additional, corroborative evidence to bolster such a revolutionary proposal. For the present, at least, there is none, while the burden of evidence points to the more traditional framework as the more likely. In particular, these new data from the Afridar sites point out some of the real problems inherent in interpreting the archaeological record. They underline the importance of the reliability of samples and their ascription to archaeological contexts they are meant to date. ${ }^{20}$

\footnotetext{
${ }^{18}$ This site is located about $15 \mathrm{~km}$ south of Tel Aviv, on the Mediterranean Littoral.

${ }^{19}$ For the sites of HIT and Palmahim Quarry the reason lies in the nature of the samples, most of which consisted of minute quantities of carbonized material too small for conventional dating. Unfortunately, no funding was available for AMS determinations.
} 
To disregard, for example, the obvious signs of disparity in material culture between the neighboring sites of Hartuv and HIT, especially evident in their ceramic assemblages, in favor of a ${ }^{14} \mathrm{C}$ determination that suggests these sites were contemporarily occupied, would negate a whole delicate web of information that indicates these sites were sequentially occupied in EB I with no overlap. The correlation is admittedly uneasy and consequently we need to look further and check our data, and also be aware of the limitations that may be placed upon them.

The ${ }^{14} \mathrm{C}$ determinations discussed above may come as a disappointment to those expecting precise, absolute dates for the chrono-cultural periodization of the late prehistory of the southern Levant and contemporary periods in Egypt. However, while ${ }^{14} \mathrm{C}$ data have failed until now to give us great precision in absolute chronology, they do offer us some assurances regarding our traditional assignment of cultural horizons to general time slots and to the validity of relative cultural sequences. The present state of research indicates that there is a pressing need for more and better determinations (e.g. Fischer 2000) based on short-life samples that will allow for greater precision.

Clearly, a holistic rather than a parochial approach to the problem of chronology is indicated. Only by collating all relevant information-including ${ }^{14} \mathrm{C}$ determinations - can we hope to illuminate the archaeological record that will provide a better and more accurate understanding of the chronological progression of material culture in the late prehistoric and earliest historic periods of the southern Levant and Egypt.

\section{ACKNOWLEDGMENTS}

The author particularly thanks E C M van den Brink for his generous help in explaining the intricacies of Egyptian chronology, sharing expertise on serekhs and offering incisive and helpful comments on earlier versions of this paper. Grateful thanks are extended to Stan Hendrickx for providing information on ${ }^{14} \mathrm{C}$ dates from Egypt, correcting Table 1, and pointing out several references cited. Ram Gophna helped enormously with encouragement and critical remarks conveyed in numerous casual conversations. The text benefited from advice of Hendrik Bruins and unknown readers. Hamoudi Khalaily kindly permitted me to cite the ${ }^{14} \mathrm{C}$ determinations from Afridar, Area F. Amihai Mazar kindly shared information on the cultural horizon of the published ${ }^{14} \mathrm{C}$ determinations from Tel Bet She'an. Michal Druk drew the map and Dror Segal initiated the exchange of ${ }^{14} \mathrm{C}$ data from the Afridar sites so that they can be published here. ${ }^{21}$

\footnotetext{
${ }^{20}$ The usual problems of "old wood effect" and residual and intrusive samples must be taken very seriously and the importance of stratigraphic provenience cannot, in this instance, be overstressed.

${ }^{21}$ As quid pro quo, Golani and Segal (forthcoming) will publish the determinations from Area G.
} 


\section{REFERENCES}

Aardsma GE. 2001. New radiocarbon dates for the reed mat from the Cave of the Treasure, Israel. Radiocarbon. This volume.

Amiran, R. 1969. Ancient Pottery of the Holy Land. Massada, Jerusalem.

Amiran R. 1974. An Egyptian Jar Fragment with the Name of Narmer from Arad. Israel Exploration Journal 24:4-12.

Amiran R 1978. The Date of the End of the EB II City of Arad. Israel Exploration Journal 28:182-4.

Amiran R, Gophna R. 1992. The correlation between lower Egypt and southern Canaan during the EB I Period. In: van den Brink ECM, editor. The Nile delta in transition: 4th-3rd millennium BC. Tel Aviv. p 35760.

Ben-Tor A. 1992. The Early Bronze age. In: Ben-Tor A, editor. The archaeology of ancient Israel. New Haven: Yale University Press. p 81-124.

Brandl B. 1992. Evidence for Egyptian colonization in the southern coastal plain and lowlands of Canaan during the EB I Period. In: van den Brink ECM, editor. The Nile delta in transition: 4th-3rd millennium BC. Tel Aviv. p 441-77.

Braun E. 1989. The transition from the Chalcolithic to the Early Bronze age in northern Israel and Transjordan: is there a missing link? In: de Miroschedji P, editor. L'urbanisation de la Palestine à l'âge du Bronze ancien: bilan et perspectives des recherches actuelles. [Actes du Colloque d'Emmaüs: 20-24 Octobre 1986]. Oxford: British Archaeological Reports. p 7-28.

Braun E. 1996. Cultural diversity and change in the Early Bronze I of Israel and Jordan: towards an understanding of the chronological progression and patterns of regionalism in Early Bronze society. [PhD thesis]. Tel Aviv University.

Braun E. 2000. Area G at Afridar, Palmahim Quarry 3, and the earliest pottery of Early Bronze age I: Part of the missing link. In: Philip G, Baird D, editors. $\mathrm{Ce}$ ramics and change in the Early Bronze age of the southern Levant. Sheffield: Sheffield Academic Press. p 113-28.

Braun E, Gophna R. Forthcoming. Excavations at Afridar, Ashqelon, Area G. 'Atiqot.

Braun E, van den Brink ECM. 1998. Some comments on the Late EB I sequence of Canaan and the relative dating of tomb U-j at Umm el Ga ab and graves 313 and 787 from Minshat Abu Omar with imported ware: views from Egypt and Canaan. Egypt and the Levant 7:71-94

Callaway JA, Weinstein JM. 1977. Radiocarbon dating of Palestine in the Early Bronze age. Bulletin of the American Schools of Oriental Research 225:1-16.

Clédat J. 1913. Les vases de El-Beda. Annales des Service des Antiquities de l'Egypte 13:115-24.

DHKPRP [The David H Koch Pyramids Radiocarbon Project]. 1999. Dating the pyramids. Archaeology
September/October: 25-33.

Dreyer G. 1992. Recent discoveries in the U-cemetery at Abydos. In: van den Brink ECM, editor. The Nile delta in transition: 4th-3rd millennium BC. Proceedings of the seminar held in Cairo, 21-24 October, 1990. The Netherlands Institute of Archaeology and Arabic Studies. Tel Aviv. p 293-300.

Dreyer G. 1998. Umm el-Qaab I: Das prädynastische Königsgrab U-j und seine frühen Schriftzeugnisse. Mainz: Verlag Philipp von Zabern. In German.

Emery WB. 1961. Archaic Egypt. Harmondsworth-Middlesex: Pelican.

Fischer PM. 2000. The Early Bronze age at Tell Abu alKharaz, Jordan Valley: a study of pottery typology, and provenance. radiocarbon dates and the synchronization of Palestine and Egypt during Dynasty 0-2. In: Phillip G, Baird D, editors. Breaking with the past: ceramics and change in the Early Bronze age of the southern Levant. Sheffield: Sheffield Academic Press. p. 201-32.

Gardiner A. 1973. Egyptian grammar. Third edition, revised. London: Oxford University Press.

Gibson S, Ibbs B, Kloner A. 1991. The Sataf Project of landscape archaeology in the Judaean Hills: a preliminary report on four seasons of survey and excavation (1987-89). Levant XXIII:29-54.

Golani A. 1997. New salvage excavations of the Early Bronze I Period in the region of the Ashqelon Marina. In: 23rd Archaeological Conference in Israel: $a b$ stracts of lectures. Jerusalem: The Israel Exploration Society. p 16

Golani A, Segal D. Forthcoming. Redefining the onset of the Early Bronze age in southern Canaan: new evidence of ${ }^{14} \mathrm{C}$ dating from Ashkelon Afridar. Festschrift in honor of Ram Gophna.

Gilead I. 1994. The history of the Chalcolithic settlement in the Nahal Beer Sheva area: the radiocarbon aspect. Bulletin of the American Schools of Oriental Research 296:1-13.

Greenberg R, Porat N. 1996. A third millennium pottery production center: typology, petrography, and provenance of the metallic ware of northern Israel and adjacent regions. Bulletin of the American Schools of Oriental Research 301:5-24.

Hassan F, Robinson SW. 1987. High-precision radiocarbon chronology of ancient Egypt and comparisons with Nubia, Palestine, and Mesopotamia. Antiquity 61:119-35.

Hendrickx S. 1996. The relative chronology of the Naqada culture: problems and possibilities. In: Spencer J, editor. Aspects of early Egypt. London: British Museum Press. p 36-69.

Hendrickx S. 1999. La chronologie de la préhistoire tardive et des débuts de l'histoire de l'Egypte. Archéo-Nil 9:13-81, 99-107.

Hennessy JB. 1967. The foreign relations of Palestine 
during the Early Bronze Age. London: Quaritch.

Joffe A H, Dessel JP. 1995. Redefining chronology and terminology for the Chalcolthic of the southern Levant. Current Anthropology 36(3):507-18.

Kaiser W. 1957. Zur inneren Chronologie der Nakadakultur. Archaeologia Geographica 6:69-77.

Kantor HJ. 1992. The relative chronology of Egypt and its foreign correlations before the First Intermediate Period. In: Ehrich RW, editor. Chronologies in Old World archaeology. Third edition. Chicago: University of Chicago Press. p 3-21.

Kempinski A, Gilead I, 1991. New excavations at Tel Erani: a preliminary report of the 1985-1988 seasons. Tel Aviv 18:164-192.

Kempinski A, Niemeier W-D. editors. 1990. Excavations at Kabri: preliminary report of 1989: season 4. Tel Aviv: Tel Kabri Expedition.

Khalaily H. Forthcoming. Site F: an Early Bronze age site at Ashqelon. 'Atiqot.

Levy TE, van den Brink ECM, Goren Y, Alon D. 1995. New light on king Narmer and the protodynastic Egyptian presence in Canaan. Biblical Archaeologist 58:26-35.

Mazar A. 1990. Archaeology of the Land of the Bible: 10,000 to 586 BCE. New York: Doubleday.

Mazar A, de Miroschedji P. 1996. Hartuv, an aspect of the Early Bronze culture of southern Israel. Bulletin of American Schools of Oriental Research 302:1-40.

de Miroschedji P. 1976. Contribution à l'etude de l'urbanisation en Palestine à l'age du bronze ancien. Thèse présentée à l'Université de Paris I en vue du doctorat de 3e cycle (specialité: archéologie orientale).

O'Brien A. 1996. The Serekh as an aspect of the iconography of early kingship. Journal of the American Research Center in Egypt 33:123-38.

Oren ED, Yekutieli Y. 1992. Taur Ikhbeineh: earliest evidence for Egyptian interconnections. In: van den Brink ECM, editor. The Nile delta in transition: 4th$3 r$ millennium BC. Proceedings of the seminar held in Cairo, 21-24 October, 1990. The Netherlands Institute of Archaeology and Arabic Studies. Tel Aviv. p 361-84.

Petrie WFM. 1953. Corpus of Proto-dynastic pottery. London: British School of Archaeology in Egypt.
Porat N. 1987. Trade of pottery between Egypt and Cana' an in ancient times. Bulletin of the Israeli Academic Center in Cairo 8:2-4.

Redford DB. 1992. Egypt, Canaan, and Israel in ancient times. Princeton: Princeton University Press.

Segal D, Carmi I. 1996. Rehovot radiocarbon date List V. 'Atiqot XXIX. Supplement:79-106.

Stager L. 1992. The periodization of palestine from the Neolithic through Early Bronze times. In: Ehrich RW, editor. Chronologies in Old World archaeology. Third edition. Chicago: University of Chicago Press. p 2260.

Stuiver M, Reimer PJ. 1993. University of Washington Quarternary Isotope Lab radiocarbon calibration program Rev. 3.0. Radiocarbon 35(2):215-30.

Stuiver M, Reimer PJ. 2000. Radiocarbon Calibration Program 2000, Rev 4.3. University of Washington Quarternary Isotope Lab (based on Stuiver and Reimer 1993).

Tutundzic SP. 1989. Relations between Late Predynastic Egypt and Palestine: some elements and phenomena. In: de Miroschedji P, editor. L'urbanisation de la Palestine à l'âge du Bronze ancien: bilan et perspectives des recherches actuelles. [Actes du Colloque d'Emmaüs: 20-24 Octobre 1986]. Oxford: British Archaeological Reports. p 423-32.

van den Brink ECM. 1996. The incised serekh-signs of Dynasties O-1, Part I: complete vessels. In: Spencer J, editor. Aspects of early Egypt. London: British Museum Press.

Ward WA.1991. Early contacts between Egypt, Canaan, and Sinai: remarks on the paper by Amnon Ben-Tor. Bulletin of the American Schools of Oriental Research 281:11-26.

Wignall SJ. 1998. The identification of the Late Prehistoric Serekh. Göttinger Miszellen 162:93-105.

Wilkinson RH. 1985. The Horus name and the form and significance of the Serek $h$ in the royal Egyptian titulary. The Journal for the Society of the Study of Egyptian Antiquities 25:99-104.

Wilkinson TA. 1999. Early Dynastic Egypt. London: Routledge.

Yeivin S. 1960. Early contacts between Canaan and Egypt. Israel Exploration Journal 10:193-203. 


\section{APPENDIX}

Table $1{ }^{14} \mathrm{C}$ dates form Afridar, Site $\mathrm{E}^{\mathrm{A}}$

\begin{tabular}{|c|c|c|c|c|}
\hline Sample nr & $\mathrm{BP}$ & Material & Calibrated Ranges, $\mathrm{BCE}^{\mathrm{b}}$ & $\begin{array}{r}\text { Probability } \\
1 \sigma=68.3 \\
2 \sigma=94.2\end{array}$ \\
\hline RT2157 & $4945 \pm 55$ & Charcoal & $\begin{array}{l}3780-3656 \\
3913-3878,3803-3642\end{array}$ & $\begin{array}{l}1 \sigma \\
2 \sigma\end{array}$ \\
\hline RT2219 & $4755 \pm 45$ & Charcoal & $\begin{array}{l}3637-3548,3544-517,3400-3384 \\
3644-3498,3461-3376\end{array}$ & $\begin{array}{l}1 \sigma \\
2 \sigma\end{array}$ \\
\hline RT2254 & $5065 \pm 45$ & $\begin{array}{l}\text { Charcoal and olive } \\
\text { pip }\end{array}$ & $\begin{array}{l}3956-3792 \\
3966-3758,3739-3730,3723-3713\end{array}$ & $\begin{array}{l}1 \sigma \\
2 \sigma\end{array}$ \\
\hline RT2255 & $4805 \pm 65$ & $\begin{array}{l}\text { Carbonized } \\
\text { olive pip }\end{array}$ & $\begin{array}{l}3650-3622,3601-3523 \\
3705-3500,3455-3445,3434-3378\end{array}$ & $\begin{array}{l}1 \sigma \\
2 \sigma\end{array}$ \\
\hline RT2256 & $5055 \pm 70$ & Charcoal & $\begin{array}{l}3959-3766,3716-3715 \\
3981-3694,3680-3664\end{array}$ & $\begin{array}{l}1 \sigma \\
2 \sigma\end{array}$ \\
\hline RT2258 & $4900 \pm 55$ & Charcoal & $\begin{array}{l}3709-3643 \\
3788-3634,3554-3541\end{array}$ & $\begin{array}{l}1 \sigma \\
2 \sigma\end{array}$ \\
\hline RT2272 & $4890 \pm 70$ & $\begin{array}{l}\text { Charcoal and olive } \\
\text { pip }\end{array}$ & $\begin{array}{l}3710-3639 \\
3889-3883,3797-3625,3591-3525\end{array}$ & $\begin{array}{l}1 \sigma \\
2 \sigma\end{array}$ \\
\hline RT2469 & $4990 \pm 45$ & Charcoal & $\begin{array}{l}3891-3882,3798-3707 \\
3940-3856,3851-3840,3820-3659\end{array}$ & $\begin{array}{l}1 \sigma \\
2 \sigma\end{array}$ \\
\hline RT2634 & $5170 \pm 100$ & Olive pips & $\begin{array}{l}4215-4205,4044-3937,3876-3871, \\
3862-3807 \\
4232-3756,3745-3712\end{array}$ & $\begin{array}{l}1 \sigma \\
2 \sigma\end{array}$ \\
\hline
\end{tabular}

${ }^{a}$ Special thanks to $\mathrm{H}$ Khalaily for making these data available to me prior to their publication.

bThese dates have been computed with Stuiver and Reimer (1993, 2000). The different ranges indicated here represent different probabilities within the 1 and 2 sigma ranges, not noted here for lack of space.

Table $2{ }^{14} \mathrm{C}$ samples ${ }^{\mathrm{a}}$ from Afridar, Area G (Locus 36)

\begin{tabular}{|c|c|c|c|c|c|}
\hline Sample nr & BP & Material & $\begin{array}{l}\text { Calibrated age } \\
\text { ranges }^{\mathrm{b}}\end{array}$ & $\begin{array}{c}\text { Relative area } \\
\text { under probability } \\
\text { distribution }\end{array}$ & $\begin{array}{l}\text { Probability } \\
1 \sigma=68.3 \\
2 \sigma=94.2\end{array}$ \\
\hline \multirow[t]{2}{*}{ RT-2644 } & $4945 \pm 45$ & Charcoal, olive wood & $\begin{array}{l}3764-3718 \\
3714-3689 \\
3683-3663\end{array}$ & $\begin{array}{l}0.493 \\
0.288 \\
0.219\end{array}$ & $1 \sigma$ \\
\hline & & & $\begin{array}{l}3893-3881 \\
3799-3644\end{array}$ & $\begin{array}{l}0.019 \\
0.981\end{array}$ & $2 \sigma$ \\
\hline \multirow[t]{2}{*}{ RT-2645 } & $4890 \pm 30$ & Charcoal, olive wood & $\begin{array}{l}3697-3677 \\
3669-3648\end{array}$ & $\begin{array}{l}0.467 \\
0.533\end{array}$ & $1 \sigma$ \\
\hline & & & $\begin{array}{l}3725-3725 \\
3711-3638\end{array}$ & $\begin{array}{l}0.001 \\
0.999\end{array}$ & $2 \sigma$ \\
\hline \multirow[t]{3}{*}{ RT-2647 } & $4855 \pm 30$ & Charcoal, olive wood & $\begin{array}{l}3689-3683 \\
3663-3637\end{array}$ & $\begin{array}{l}0.076 \\
0.869\end{array}$ & $1 \sigma$ \\
\hline & & & $3704-3632$ & 0.890 & $2 \sigma$ \\
\hline & & & 3559-3539 & 0.110 & \\
\hline
\end{tabular}

${ }^{a}$ Three samples, all derived from locus 36 , were collected from the same specimen of carbonized olive wood, albeit at different times. The results are organized in Table 2.

${ }^{b}$ All calibrations are according to Stuiver and Reimer (1993, 2000). 
Table 3 A series of ${ }^{14} \mathrm{C}$ dates from EB I deposits at Kabria

\begin{tabular}{|c|c|c|c|c|c|}
\hline Field nr ${ }^{\mathrm{b}}$ & $\mathrm{BP}^{\mathrm{c}}$ & Stratum & Locus & Calibrated ranges, $\mathrm{BCE}^{\mathrm{d}}$ & $\begin{array}{r}\text { Probability } \\
1 \sigma=68.3 \\
2 \sigma=94.2\end{array}$ \\
\hline \multirow[t]{2}{*}{4650} & $4430 \pm 60$ & 9/EB I & 1021 & $\begin{array}{l}\text { 3311-3236, 3171-3161, 3116-3112, } \\
3103-2923\end{array}$ & $1 \sigma$ \\
\hline & & & & 3349-2905 & $2 \sigma$ \\
\hline \multirow[t]{2}{*}{4660} & $4545 \pm 60$ & 9/EB I & 1039 & $\begin{array}{l}3365-3307,3265-3265,3238-3168, \\
3163-3102\end{array}$ & $1 \sigma$ \\
\hline & & & & $3498-3459,3377-3081,3067-3030$ & $2 \sigma$ \\
\hline \multirow[t]{2}{*}{4658} & $4515 \pm 65$ & 10/EB I & 1082 & $3358-3095$ & $1 \sigma$ \\
\hline & & & & $\begin{array}{l}3493-3469,3373-3013,2981-2960, \\
2952-2927\end{array}$ & $2 \sigma$ \\
\hline \multirow[t]{2}{*}{4684} & $4450 \pm 60$ & 10/EB I & 1040 & $\begin{array}{l}3332-3214,3187-3156,31230-3016, \\
2977-2968,2948-2936\end{array}$ & $1 \sigma$ \\
\hline & & & & $3355-2915$ & $2 \sigma$ \\
\hline \multirow[t]{2}{*}{$4684^{\mathrm{e}}$} & $4380 \pm 60$ & 11/Early & 1084 & $3091-3057,3047-2911$ & $1 \sigma$ \\
\hline & & EB I & & $3328-3222,3175-3158,3120-2884$ & $2 \sigma$ \\
\hline \multirow[t]{2}{*}{4688} & $4355 \pm 60$ & 11/Early & 1084 & $3080-3069,3027-2899$ & $1 \sigma$ \\
\hline & & EB I & & $3261-3241,3166-3164,3101-2880$ & $2 \sigma$ \\
\hline \multirow[t]{2}{*}{$4688 / 1$} & $4660 \pm 65$ & 11/Early & 1084 & $3616-3612,3520-3361$ & $1 \sigma$ \\
\hline & & EB I & & $3206-3195,3149-3140$ & $2 \sigma$ \\
\hline
\end{tabular}

${ }^{\mathrm{a}}$ All dates are derived from Kempinski and Niemeier (1990:8)

${ }^{\mathrm{b}}$ Neither laboratory nor sample code is specifically indicated in the publication.

${ }^{\mathrm{c}} \mathrm{YBP}=$ Years before present.

${ }^{\mathrm{d}}$ These dates have been computed according to Stuiver and Reimer (1993, 2000).

${ }^{\mathrm{e}}$ The repetition of this number is probably a mistake in the report.

Table $4{ }^{14} \mathrm{C}$ dates from Phase IV (Early EB I) at Taur Ikhbeineh ${ }^{\mathrm{a}}$

\begin{tabular}{|c|c|c|c|c|}
\hline Sample nr & $\mathrm{BP}$ & Material & Calibrated ranges, $\mathrm{BCE}^{\mathrm{b}}$ & $\begin{array}{l}\text { Probability } \\
1 \sigma=68.3 \\
2 \sigma=94.2\end{array}$ \\
\hline PTA 4658 & $4590 \pm 40$ & Charred wheat & $\begin{array}{l}3487-3474,3370-3348 \\
3500-3452,3441-3434,3378-3330,3215- \\
3182,3157-3121\end{array}$ & $\begin{array}{l}1 \sigma \\
2 \sigma\end{array}$ \\
\hline PTA 4659 & $4580 \pm 45$ & Charred wheat & $\begin{array}{l}3369-3342,3147-3143 \\
3500-3453,3440-3434,3378-3309,3236- \\
3169,3162-3102\end{array}$ & $\begin{array}{l}1 \sigma \\
2 \sigma\end{array}$ \\
\hline PTA 4654 & $4650 \pm 45$ & Charred wheat & $\begin{array}{l}3505-3426,3382-3364 \\
3623-3597,3523-3351\end{array}$ & $\begin{array}{l}1 \sigma \\
2 \sigma\end{array}$ \\
\hline PTA 4655 & $4620 \pm 45$ & Charred wheat & $\begin{array}{l}3498-3459,3377-3356 \\
3517-3359,3207-3194,3150-3140\end{array}$ & $\begin{array}{l}1 \sigma \\
2 \sigma\end{array}$ \\
\hline PTA 4679 & $4500 \pm 60$ & Charred wheat & $\begin{array}{l}3352-3088,3058-3042 \\
3368-3010,2984-2924\end{array}$ & $\begin{array}{l}1 \sigma \\
2 \sigma \\
1 \sigma\end{array}$ \\
\hline
\end{tabular}

${ }^{a}$ All dates are taken from: Oren and Yekutieli (1992).

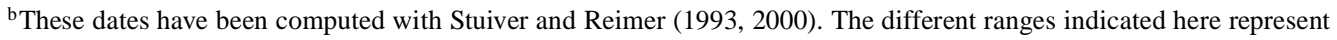
probabilities within the 1 and 2 sigma ranges, not noted here for lack of space. 
Table $5{ }^{14} \mathrm{C}$ dates from Afridar, Site F (EB I, early, post initial phase) ${ }^{\mathrm{a}}$

\begin{tabular}{|c|c|c|c|c|c|}
\hline Sample nr & Context & BP & Material & Calibrated ranges, $\mathrm{BCE}^{\mathrm{b}}$ & $\begin{array}{r}\text { Probability } \\
1 \sigma=68.3 \\
2 \sigma=94.2\end{array}$ \\
\hline RT2247/8 & Stratum I & $4545 \pm 105$ & $\begin{array}{l}\text { Charcoal/ } \\
\text { organic }^{c}\end{array}$ & $\begin{array}{l}3495-3467,3374-3089,3058-3043 \\
3627-3584,3533-2916\end{array}$ & $\begin{array}{l}1 \sigma \\
2 \sigma\end{array}$ \\
\hline RT2567 & Stratum I & $4577 \pm 45$ & Charcoal & $\begin{array}{l}3368-3341,3205-3203,3148-3142 \\
3499-3457,3377-3307,3237-3168, \\
3163-3102\end{array}$ & $\begin{array}{l}1 \sigma \\
2 \sigma\end{array}$ \\
\hline
\end{tabular}

a Particular thanks are due to $\mathrm{H}$ Khalaily for making these data available to me prior to their publication.

b These dates have been computed with Stuiver and Reimer (1993, 2000). The different ranges indicated here represent different probabilities within the 1 and 2 sigma ranges, not noted here for lack of space.

${ }^{\mathrm{c}}$ This determination was made from two separate samples, combined; hence the double number. Presumably they were derived from the same find spot.

Table 6 Selected ${ }^{14} \mathrm{C}$ dates from Chalcolithic sites in Israel ${ }^{\mathrm{a}}$

\begin{tabular}{|c|c|c|c|c|c|}
\hline Sample nr & Site, etc. & $\mathrm{BP}$ & Material & Calibrated Ranges, $\mathrm{BCE}^{\mathrm{b}}$ & $\begin{array}{r}\text { Probability } \\
1 \sigma=68.3 \\
2 \sigma=94.2\end{array}$ \\
\hline \multirow[t]{2}{*}{ RT-1329 } & \multirow[t]{2}{*}{$\begin{array}{l}\text { Shiqmim/hearth } \\
\text { SRIII }\end{array}$} & \multirow[t]{2}{*}{$4260 \pm 80$} & \multirow[t]{2}{*}{$?$} & $\begin{array}{l}2918-2865,2806-2780,2760- \\
2762,2717-2710\end{array}$ & $1 \sigma$ \\
\hline & & & & $\begin{array}{l}3082-3067, \quad 3029-2656, \quad 2655- \\
2621,2607-2602\end{array}$ & $2 \sigma$ \\
\hline \multirow[t]{2}{*}{ RT-1332 } & \multirow[t]{2}{*}{$\begin{array}{l}\text { Shiqmim/Room } \\
\text { SR6/Sub-phase BII }\end{array}$} & \multirow[t]{2}{*}{$4700 \pm 80$} & \multirow[t]{2}{*}{$?$} & $3633-3557,3540-3368$ & $1 \sigma$ \\
\hline & & & & $3647-3345$ & $2 \sigma$ \\
\hline \multirow[t]{2}{*}{ RT-1339 } & \multirow{2}{*}{$\begin{array}{l}\text { Shiqmim/Loc. } \\
\text { Z201/PhaselI/burial } \\
\text { pit/Chalcolithic }\end{array}$} & \multirow[t]{2}{*}{$4940 \pm 70$} & \multirow[t]{2}{*}{$?$} & $3787-3650$ & $1 \sigma$ \\
\hline & & & & $\begin{array}{l}3940-3856,3849-3843,3819- \\
3636,3549-3543\end{array}$ & $2 \sigma$ \\
\hline \multirow[t]{2}{*}{ RT-860B } & \multirow{2}{*}{$\begin{array}{l}\text { Gilat/Loc.92/ } \\
\text { Bask.595/Stratum II }\end{array}$} & \multirow[t]{2}{*}{$4800 \pm 135$} & \multirow[t]{2}{*}{ Charcoal } & $3705-3498,3460-3377$ & $1 \sigma$ \\
\hline & & & & $\begin{array}{l}\text { 3937-3875, 3872-3862, } \\
3809-3340 \text { 3206-3198, } \\
3149-3141\end{array}$ & $2 \sigma$ \\
\hline \multirow[t]{2}{*}{ ETH15428 } & \multirow[t]{2}{*}{$\begin{array}{l}\text { Shoham/Cave/ } \\
\text { domestic context }\end{array}$} & \multirow{2}{*}{$\begin{array}{l}3945 \pm 65 \\
\left(\mathrm{AMS}^{\mathrm{c}}\right. \\
\text { date })\end{array}$} & \multirow[t]{2}{*}{$\begin{array}{l}\text { Olive } \\
\text { stone }\end{array}$} & $\begin{array}{l}3893-3881,3799-3689,3683- \\
3663\end{array}$ & $1 \sigma$ \\
\hline & & & & $3955-3643$ & $2 \sigma$ \\
\hline \multirow[t]{2}{*}{ RT1645 } & \multirow{2}{*}{$\begin{array}{l}\text { Nahal Mishmar } \\
\text { Cave } 3\end{array}$} & \multirow[t]{2}{*}{$5535 \pm 75$} & \multirow[t]{2}{*}{ Straw mat } & $4455-4333$ & $1 \sigma$ \\
\hline & & & & $3644-3498,3461-3376$ & $2 \sigma$ \\
\hline \multirow[t]{2}{*}{ RT1408 } & \multirow{2}{*}{$\begin{array}{l}\text { Nahal Mishmar } \\
\text { Cave 1, hall B }\end{array}$} & \multirow[t]{2}{*}{$5575 \pm 90$} & \multirow{2}{*}{$\begin{array}{l}\text { Remains } \\
\text { of } \\
\text { straw mats }\end{array}$} & $4494-4470,4463-4339$ & $1 \sigma$ \\
\hline & & & & $4598-4248$ & $2 \sigma$ \\
\hline
\end{tabular}

${ }^{\text {a All samples with the RT designation are taken from Gilead } 1994 \text { with the exception of those from Nahal Mishmar that }}$ appear in: Segal and Carmi (1969:93-4). The single ETH sample is from Liphschitz et al. 1996.

${ }^{b}$ These dates have been computed with Stuiver and Reimer (1993,2000). The different ranges indicated here represent different probabilities within the 1 and 2 sigma ranges, not noted here for lack of space.

${ }^{\mathrm{c}} \mathrm{AMS}=$ accelerator mass spectrometry. 
Table $7{ }^{14} \mathrm{C}$ samples from Afridar, Area E

\begin{tabular}{llllc}
\hline & & & & Probability \\
Sample nr & BP & Material & Calibrated ranges, BCE $^{\text {a }}$ & $\begin{array}{c}1 \sigma=68.3 \\
2 \sigma=94.2\end{array}$ \\
\hline AAR-4500 & $4730 \pm 55$ & Charred olive stones & $3634-3555,3541-3500$, & $1 \sigma$ \\
& & & $3434-3378$ & $2 \sigma$ \\
& & & $3643-3367$ & $1 \sigma$ \\
AAR-4501 & \multirow{2}{*}{$4755 \pm 45$} & Wood ash with burnt seeds & $3315-3410,3383-3357$ & $2 \sigma$ \\
& & & $3628-3581,3536-3334$, & \\
\hline
\end{tabular}

aThese dates have been computed with Stuiver and Reimer (1993, 2000). The different ranges indicated here represent different probabilities within the 1 and 2 sigma ranges, not noted here for lack of space.

Table 8 Selected ${ }^{14} \mathrm{C}$ samples from Protodynastic and Dynasty 1 contexts in Egypt (all dates from Hendrickx 1999)

\begin{tabular}{|c|c|c|c|c|c|}
\hline Site/context & Sample nr & $\mathrm{BP}$ & $\begin{array}{l}\text { Calibrated } \\
\text { age ranges }\end{array}$ & $\begin{array}{l}\text { Relative area } \\
\text { under probability } \\
\text { distribution }\end{array}$ & $\begin{array}{c}\text { Probability } \\
1 \sigma=68.3 \\
2 \sigma=94.2\end{array}$ \\
\hline \multirow[t]{2}{*}{ Abydos, tomb U-j } & \multirow[t]{2}{*}{ Hd 13058-1295 } & \multirow[t]{2}{*}{$4595 \pm 25$} & $\begin{array}{l}3486-3474 \\
3370-3351\end{array}$ & $\begin{array}{l}0.281 \\
0.719\end{array}$ & $1 \sigma$ \\
\hline & & & $\begin{array}{l}3497-3461 \\
3376-3339 \\
3206-3194\end{array}$ & $\begin{array}{l}0.358 \\
0.616 \\
0.025\end{array}$ & $2 \sigma$ \\
\hline \multirow[t]{2}{*}{ Abydos, tomb $\mathrm{U}-\mathrm{j}$} & \multirow[t]{2}{*}{ Hd 13057-1295 } & \multirow[t]{2}{*}{$4470 \pm 30$} & $\begin{array}{l}3327-3223 \\
3174-3159 \\
3119-3106 \\
3105-3090 \\
3057-3045\end{array}$ & $\begin{array}{l}0.686 \\
0.093 \\
0.071 \\
0.085 \\
0.065\end{array}$ & $1 \sigma$ \\
\hline & & & $\begin{array}{l}3339-3207 \\
3196-3148 \\
3141-3078 \\
3071-3025\end{array}$ & $\begin{array}{l}0.548 \\
0.138 \\
0.190 \\
0.125\end{array}$ & $2 \sigma$ \\
\hline \multirow[t]{2}{*}{ Abydos, tomb $U_{-j}$} & \multirow[t]{2}{*}{ Bin- 4673} & \multirow[t]{2}{*}{$4591 \pm 41$} & $\begin{array}{l}3497-3462 \\
3376-3335 \\
3210-3191 \\
3153-3156\end{array}$ & $\begin{array}{l}0.327 \\
0.470 \\
\underline{105} \\
0.098\end{array}$ & $1 \sigma$ \\
\hline & & & $\begin{array}{l}3505-3426 \\
3424-3413 \\
3382-3307 \\
3238-3168 \\
3163-3102\end{array}$ & $\begin{array}{l}0.311 \\
0.006 \\
0.380 \\
0.153 \\
0.149\end{array}$ & $2 \sigma$ \\
\hline \multirow[t]{2}{*}{$\begin{array}{l}\text { Abydos, tomb } \\
\text { B19, Hor-Aha }\end{array}$} & \multirow[t]{2}{*}{ Hd13054-1292 } & \multirow[t]{2}{*}{$4535 \pm 40$} & $\begin{array}{l}3356-3325 \\
3322-3313 \\
3231-3172 \\
3160-3117 \\
3110-3104\end{array}$ & $\begin{array}{l}0.219 \\
0.046 \\
0.396 \\
0.303 \\
0.037\end{array}$ & $1 \sigma$ \\
\hline & & & $\begin{array}{l}3365-3256 \\
3249-3098\end{array}$ & $\begin{array}{l}0.367 \\
0.633\end{array}$ & $2 \sigma$ \\
\hline \multirow[t]{2}{*}{$\begin{array}{l}\text { Abydos, tomb } \\
\text { B19, Hor-Aha }\end{array}$} & \multirow[t]{2}{*}{ Hd13055-1294 } & \multirow[t]{2}{*}{$4505 \pm 20$} & $\begin{array}{l}3338-3307 \\
3268-3265 \\
3238-3207 \\
3194-3168 \\
3163-3150 \\
3139-3102\end{array}$ & $\begin{array}{l}0.288 \\
0.016 \\
0.233 \\
0.182 \\
0.082 \\
0.260\end{array}$ & $1 \sigma$ \\
\hline & & & $\begin{array}{l}3343-3261 \\
3241-3145 \\
3145-3100\end{array}$ & $\begin{array}{l}0.343 \\
0.450 \\
0.207\end{array}$ & $2 \sigma$ \\
\hline Saqqara tomb 3503, Djer & BM 229 & $4520 \pm 65$ & $\begin{array}{l}3351-3306 \\
3302-3264 \\
3239-3168 \\
3163-3102\end{array}$ & $\begin{array}{l}0.210 \\
0.162 \\
0.339 \\
0.289\end{array}$ & $1 \sigma$ \\
\hline
\end{tabular}


Table 9 Selected ${ }^{14} \mathrm{C}$ Samples from Middle and Late EB I contexts from southern sites

\begin{tabular}{|c|c|c|c|c|c|c|}
\hline Site/context & Sample nr & $\mathrm{BP}$ & Material & $\begin{array}{l}\text { Calibrated } \\
\text { age ranges }\end{array}$ & $\begin{array}{l}\text { Relative area } \\
\text { under probability } \\
\text { distribution }\end{array}$ & $\begin{array}{c}\text { Probability } \\
1 \sigma=68.3 \\
2 \sigma=94.2\end{array}$ \\
\hline \multirow[t]{2}{*}{ HIT (IV) } & \multirow[t]{2}{*}{ RT-1572 } & \multirow[t]{2}{*}{$4350 \pm 35$} & \multirow[t]{2}{*}{ Charred wood } & $\begin{array}{l}3016-2978 \\
2968-2948 \\
2935-2907\end{array}$ & $\begin{array}{l}0.467 \\
0.204 \\
0.329\end{array}$ & \multirow[t]{2}{*}{$1 \sigma$} \\
\hline & & & & $\begin{array}{l}3082-3067 \\
3030-2891\end{array}$ & $\begin{array}{l}0.044 \\
0.956\end{array}$ & \\
\hline \multirow[t]{2}{*}{ HIT (IV) } & \multirow[t]{2}{*}{ RT-1573 } & \multirow[t]{2}{*}{$4705 \pm 55$} & \multirow[t]{2}{*}{ Charcoal } & $\begin{array}{l}3625-3590 \\
3525-3497 \\
3462-3376\end{array}$ & $\begin{array}{l}0.220 \\
0.187 \\
0.593\end{array}$ & \multirow[t]{2}{*}{$1 \sigma$} \\
\hline & & & & $\begin{array}{l}3633-3556 \\
3540-3369\end{array}$ & $\begin{array}{l}0.280 \\
0.720\end{array}$ & \\
\hline HIT (IV) & RT-1576 & $4365 \pm 50$ & Charcoal & $\begin{array}{l}3078-3072 \\
3024-2911\end{array}$ & $\begin{array}{l}0.041 \\
0.959\end{array}$ & $1 \sigma$ \\
\hline \multirow[t]{2}{*}{ Hartuv (II) a8 } & \multirow[t]{2}{*}{ RT 924A } & \multirow[t]{2}{*}{$3760 \pm 110$} & \multirow[t]{2}{*}{ Charred wood } & $\begin{array}{l}2396-2390 \\
2338-2317 \\
2313-2027 \\
1993-1982\end{array}$ & $\begin{array}{l}0.013 \\
0.048 \\
0.912 \\
0.026\end{array}$ & \multirow[t]{2}{*}{$1 \sigma$} \\
\hline & & & & $2468-1885$ & 1.000 & \\
\hline \multirow[t]{2}{*}{ Hartuv (II) $)^{b 9}$} & \multirow[t]{2}{*}{ RT 924B } & \multirow[t]{2}{*}{$4645 \pm 55$} & \multirow[t]{2}{*}{ Charred wood } & $\begin{array}{l}3315-3410 \\
3383-3360\end{array}$ & $\begin{array}{l}0.820 \\
0.180\end{array}$ & $1 \sigma$ \\
\hline & & & & $\begin{array}{l}3631-3577 \\
3571-3561 \\
3538-3334 \\
3211-3190 \\
3154-3135 \\
3127-3125\end{array}$ & $\begin{array}{l}0.079 \\
0.006 \\
0.885 \\
0.015 \\
0.014 \\
0.001\end{array}$ & $2 \sigma$ \\
\hline \multirow[t]{2}{*}{$\begin{array}{l}\text { Palmahim } \\
\text { Quarry (1) }\end{array}$} & \multirow[t]{2}{*}{ RT-2649 } & \multirow[t]{2}{*}{$4405 \pm 40$} & \multirow[t]{2}{*}{ Seeds } & $\begin{array}{l}3089-3058 \\
3043-3006 \\
2994-2923\end{array}$ & $\begin{array}{l}0.227 \\
0.262 \\
0.511\end{array}$ & $1 \sigma$ \\
\hline & & & & $\begin{array}{l}3312-3235 \\
3117-3160 \\
3117-3111 \\
3104-2910\end{array}$ & $\begin{array}{l}0.096 \\
0.011 \\
0.005 \\
0.888\end{array}$ & $2 \sigma$ \\
\hline \multirow[t]{3}{*}{$\begin{array}{l}\text { Sataf }^{\mathrm{c} 0} \\
\text { (Erani C } \\
\text { phase) }\end{array}$} & \multirow[t]{3}{*}{ Oxa 3434} & \multirow[t]{3}{*}{$4590 \pm 70$} & \multirow[t]{3}{*}{ Grape seeds } & $\begin{array}{l}3502-3430 \\
3380-3326 \\
3321-3314 \\
3229-3172 \\
3160-3117 \\
3110-3104\end{array}$ & $\begin{array}{l}0.308 \\
0.275 \\
0.019 \\
0.212 \\
0.166 \\
0.020\end{array}$ & $1 \sigma$ \\
\hline & & & & $\begin{array}{l}3622-3600 \\
3523-3090 \\
3057-3046\end{array}$ & $\begin{array}{l}0.014 \\
0.980 \\
0.006\end{array}$ & $2 \sigma$ \\
\hline & & & & $\begin{array}{l}3306-3302 \\
3264-3239 \\
3168-3163 \\
3102-2883\end{array}$ & $\begin{array}{l}0.002 \\
0.002 \\
0.003 \\
0.973\end{array}$ & $2 \sigma$ \\
\hline \multirow[t]{2}{*}{ HIT (IV) } & \multirow[t]{2}{*}{ RT-1602 } & $4755 \pm 55$ & Charcoal & $\begin{array}{l}3637-3547 \\
3544-3516 \\
3401-3384\end{array}$ & $\begin{array}{l}0.683 \\
0.213 \\
0.104\end{array}$ & $1 \sigma$ \\
\hline & & & & $\begin{array}{l}3644-3497 \\
3462-3376\end{array}$ & $\begin{array}{l}0.736 \\
0.264\end{array}$ & $2 \sigma$ \\
\hline HIT (IV) & RT-1603 & $4710 \pm 80$ & Charcoal & $\begin{array}{l}3629-3580 \\
3566-3565 \\
3537-3496 \\
3466-3375\end{array}$ & $\begin{array}{l}0.269 \\
0.005 \\
0.223 \\
0.504\end{array}$ & $1 \sigma$ \\
\hline & & & & $\begin{array}{l}3655-3343 \\
3146-3144\end{array}$ & $\begin{array}{l}0.999 \\
0.001\end{array}$ & $2 \sigma$ \\
\hline
\end{tabular}


$\underline{\text { Table } 9 \text { Selected }{ }^{14} \mathrm{C} \text { Samples from Middle and Late EB I contexts from southern site }(\text { Cont'd.) }}$

\begin{tabular}{|c|c|c|c|c|c|c|}
\hline Site/context & Sample nr & $\mathrm{BP}$ & Material & $\begin{array}{l}\text { Calibrated } \\
\text { age ranges }\end{array}$ & $\begin{array}{l}\text { Relative area } \\
\text { under probability } \\
\text { distribution }\end{array}$ & $\begin{array}{l}\text { Probability } \\
1 \sigma=68.3 \\
2 \sigma=94.2\end{array}$ \\
\hline HIT (III) & RT-1604 & $4490 \pm 45$ & Emmer wheat & $\begin{array}{l}3334-3255 \\
3251-3211 \\
3190-3154 \\
3135-3098 \\
3353-3079 \\
3070-3026\end{array}$ & $\begin{array}{l}0.420 \\
0.211 \\
0.184 \\
0.185 \\
0.919 \\
0.081\end{array}$ & $2 \sigma$ \\
\hline HIT (IV) & RT-1660 & $4800 \pm 55$ & Charcoal & $\begin{array}{l}3648-3621 \\
3602-3522 \\
3697-3677 \\
3699-3502 \\
3431-3380\end{array}$ & $\begin{array}{l}0.250 \\
0.750 \\
0.024 \\
0.878 \\
0.098\end{array}$ & $\begin{array}{l}1 \sigma \\
2 \sigma\end{array}$ \\
\hline HIT (IV) & RT-1661 & $3990 \pm 90$ & Charcoal & $\begin{array}{l}2828-2823 \\
2658-2652 \\
2623-2605 \\
2604-2396 \\
2385-2342 \\
2863-2807 \\
2778-2772 \\
2760-2718 \\
2705-2274 \\
2254-2228 \\
2222-2205\end{array}$ & $\begin{array}{l}0.009 \\
0.016 \\
0.050 \\
0.807 \\
0.118 \\
0.059 \\
0.003 \\
0.029 \\
0.883 \\
0.016 \\
0.010\end{array}$ & $2 \sigma$ \\
\hline \multirow[t]{2}{*}{ HIT (III) } & RT-1662 & $4255 \pm 50$ & Charcoal & $\begin{array}{l}2916-2864 \\
2806-2779 \\
2771-2760 \\
2718-2707\end{array}$ & $\begin{array}{l}0.632 \\
0.228 \\
0.075 \\
0.066\end{array}$ & $1 \sigma$ \\
\hline & & & & $\begin{array}{l}3015-2980 \\
2962-2952 \\
2931-2838 \\
2817-2665 \\
2647-2639\end{array}$ & $\begin{array}{l}0.032 \\
0.006 \\
0.507 \\
0.449 \\
0.005\end{array}$ & $2 \sigma$ \\
\hline
\end{tabular}

${ }^{a}$ Mazar and de Miroschedji (1996).

${ }^{\mathrm{b}}$ Ibid.

${ }^{\mathrm{c}}$ Courtesy of S Gisbon whom the author wishes to thank for permission to publish this determination.

Table 10 New ${ }^{14} \mathrm{C}$ dates from Afridar, Area $\mathrm{E}$

\begin{tabular}{llllc}
\hline & & & Probability \\
Sample nr & BP & Material & Calibrated ranges, BCE ${ }^{\text {a }}$ & $\begin{array}{c}1 \sigma=68.3 \\
2 \sigma=94.2\end{array}$ \\
\hline AAR-4500 & $4730 \pm 55$ & $\begin{array}{l}\text { Charred olive } \\
\text { stones }\end{array}$ & $3634-3555,3541-3500,3434-3378$ & $1 \sigma$ \\
& & & $3643-3367$ & $2 \sigma$ \\
AAR-4501 & \multirow{2}{*}{$4755 \pm 45$} & $\begin{array}{l}\text { Wood ash with } \\
\text { burnt seeds }\end{array}$ & $3315-3410,3383-3357$ & $1 \sigma$ \\
& & & $3628-3581,3536-3334,3211-3190,3154-3135$ & $2 \sigma$ \\
\hline
\end{tabular}

aThese dates have been computed with Stuiver and Reimer $(1993,2000)$. The different ranges indicated here represent different probabilities within the 1 and 2 sigma ranges, not noted here for lack of space. 